\title{
On Construction of M\&A and Profit-making Method of China Securities Traders
}

\author{
Tan Qiuheng \\ Guosen Securities Co., Ltd. \\ Shenzhen, China \\ tanqiuheng5588@sina.com
}

\begin{abstract}
Securities traders in China are facing great challenges along with change and development of market economy as well as double pressure from macro and micro economy conditions in recent years. The securities traders should be based on existing condition and combine with market demand for realizing business innovation, and own business concepts are constantly converted in order to achieve invincible position in the intense market competition. Acquisitions and mergers in securities industry as well as expansion of company scale and capital strength are the best modes for China securities traders to deal with cruel market competition under such a macroscopic background. In the research of the paper, the author discusses aiming at current M\&A situation of securities traders, and deeply analyzes profit model of M\&A business of securities traders, thereby proposing development strategies. It is expected that the paper can play certain reference role.
\end{abstract}

Keywords-securities company; merger; acquisition and reorganization; profit model

\section{INTRODUCTION}

Domestic securities traders seek to grow larger and stronger actively in order to deal with challenges and competition from all aspects under China current background. They make effort to survive in cruel market competition. Capital, scale, business, profitability, etc. are enhanced through mergers and acquisitions in securities market. It is the most direct and rapid method for domestic securities traders under current condition[1]. Realization of maximum profit-making area has been widely concerned.

\section{DEVELOPMENT SITUATION OF SECURITIES TRADERS IN CHINA}

Securities field in China undergoes development for more than ten years. It is influenced by great background at home and abroad. A series of profound changes occur. Market system and market management are greatly changed with continuous expansion of China industry scale and prominent market change especially in recent years.

Although the stock market was influenced by global economic downturn in 2008 or so, stock indexes in Shanghai Stock Exchange and Shenzhen Stock Exchange were reduced continuously, severe market environment is gradually improved currently seven years later from the perspective of stock market. China A-share market is developed as security market with the most growth potential all over the world. When the securities market environment is improved, comprehensive governance strength in the aspect of securities trader is increased and main participants in the securities market-securities companies become stronger and stronger with development of stock market since equity division reform is also further prompted. There are hundreds of securities companies in China till present, including other innovation class securities companies such as Guotai Jun'an, Shenyin Wanguo, Citic Securities, Everbright Securities, etc., 31 regulation class securities companies such as Sealand Securities, Great Wall Securities, Sinolink Securities, United Securities, etc., and some high-risk class and disposal class securities companies[2-5].

In recent years, Profits of securities companies also show a high fluctuation state with the fluctuation of the secondary market from the perspective of profitability as shown in Tab.1 [6-8]. When the maximum increase was realized in the secondary market in 2012, the highest amount of security trade profit was also realized in recent years, which was up to 24.1 billion Yuan, net profit was up to 16.2 billion Yuan, it suffered from brief fall, and securities trader profit was also dropped [9-10]. However, the table shows that industry loss proportion of securities traders in China has shown rising trend for long term.

TABLE I. PROFIT CONDITION TABLE OF SECURITIES COMPANIES IN CHINA

\begin{tabular}{|c|c|c|c|c|c|}
\hline Year & $\mathbf{2 0 1 0}$ & $\mathbf{2 0 1 1}$ & $\mathbf{2 0 1 2}$ & $\mathbf{2 0 1 3}$ & $\mathbf{2 0 1 4}$ \\
\hline $\begin{array}{c}\text { Security company } \\
\text { quantity included } \\
\text { in statistics }\end{array}$ & 90 & 83 & 98 & 97 & 122 \\
\hline $\begin{array}{c}\text { Total profit in the } \\
\text { whole industry } \\
\text { (hundred million } \\
\text { Yuan) }\end{array}$ & 78.79 & 83.35 & 241 & 64.99 & -25.93 \\
\hline $\begin{array}{c}\text { Total average } \\
\text { profit of each } \\
\text { company (hundred } \\
\text { million Yuan) }\end{array}$ & 8754.44 & 10042 & 24591.84 & 6701 & -2315.18 \\
\hline $\begin{array}{c}\text { Total net profit in } \\
\text { the whole industry } \\
\text { (hundred million } \\
\text { Yuan) }\end{array}$ & 53.1 & 62.68 & 162.02 & 37 & -30.15 \\
\hline $\begin{array}{c}\text { Average net profit } \\
\text { of each company } \\
\text { (hundred million } \\
\text { Yuan) }\end{array}$ & 5900 & 7551.72 & 16532.87 & 3814 & -2471.31 \\
\hline $\begin{array}{c}\text { Net asset return } \\
\text { rate of the industry } \\
\text { (hundred million } \\
\text { Yuan) }\end{array}$ & 15.05 & 12.13 & 20.89 & 4.30 & -2.77 \\
\hline $\begin{array}{c}\text { Industry loss } \\
\text { proportion (\%) }\end{array}$ & 1.10 & 4.80 & 5.10 & 26.80 & 45.50 \\
\hline
\end{tabular}

Income of security traders in China is extremely dependent on the secondary market as a whole. There is stronger positive correlation between fluctuation in the secondary market and profitability of the securities 
companies. When the whole industry suffers from severe challenges, the securities traders must consider the current situation, adjust operation mode, seek new profit model and get rid of current unbeneficial situation. Therefore, securities trader mergers and acquisitions business is produced as a result.

\section{BASIC SITUATION OF MERGER, ACQUISITION AND REORGANIZATION OF SECURITIES TRADERS IN CHINA}

Domestic securities trader M\&A in China was started in 1996. M\&A of Shenyin Securities and Wanguo Securities is regarded as a prelude. The development history is only ten years till present. There are only 10 successful M\&A cases of securities traders as of the first half of 2005. Compared with merger and reorganization quantity of foreign securities companies, domestic securities companies have extremely less successful cases. However, large-scale merger and reorganizations by securities traders enter a new stage since the second half of 2005. More than ten mergers and reorganization events were implemented by securities traders in China within one year and half from June 2005 to December 2006. There were a total of 113 securities companies as of December 31, 2006, and they were reduced by $15 \%$ compared with 132 securities companies by the end of 2005. There are three most famous securities companies in early stage of China securities market-Southern Securities, Huaxia Securities and Guotai Securities. The three securities companies occupied the great proportion of China securities market for many years. Their company scale and operating performance are in the leading position in China securities traders. However, it is unfortunate that Guotai and Jun'an were merged to form Guotai Jun'an Securities, the other two companies can not avoid merger or shutdown till present, wherein Southern Securities is a securities company which is declared for shutdown following Dalian Securities, Xinhua Securities, Jiamusi Securities, etc., and Huaxia Securities was jointly acquired by Citic Securities and China Jianyin Investment (hereinafter referred to as "Jianyin Investment"). Other front-line large securities traders, such as Shenyin Wanguo, Yinhe Securities, etc., also faced the same fate. They can merely survive by relying on huge investment by Huijin Company and Jianyin Investment. Both front-line largescale securities traders and medium small securities traders are undergoing reconstruction of China securities trader pattern in securities trader shutdown, investment injection by Huijin and Jianyin, merger and acquisition of traders in failure by high-quality securities traders and foreign securities traders.
TABLE II. MERGER AND ACQUISITION CONDITION OF A PART OF SECURITIES TRADERS IN CHINA

\begin{tabular}{|c|c|c|c|}
\hline Merged party & $\begin{array}{l}\text { Merging part and } \\
\text { mode }\end{array}$ & Merged party & $\begin{array}{l}\text { Merging part and } \\
\text { mode }\end{array}$ \\
\hline $\begin{array}{l}\text { Southern } \\
\text { Securities }\end{array}$ & $\begin{array}{l}\text { Investment by Jianyin } \\
\text { (Holding) }\end{array}$ & $\begin{array}{c}\text { Tianyi } \\
\text { Securities }\end{array}$ & $\begin{array}{c}\text { Everbright Securities } \\
\text { (Acquisition) }\end{array}$ \\
\hline $\begin{array}{l}\text { HongYuan } \\
\text { Securities }\end{array}$ & $\begin{array}{l}\text { Investment by Jianyin } \\
\text { (Acquisition) }\end{array}$ & $\begin{array}{c}\text { Kunlun } \\
\text { Securities }\end{array}$ & $\begin{array}{c}\text { Everbright Securities } \\
\text { (Trusteeship) }\end{array}$ \\
\hline Qilu Securities & $\begin{array}{c}\text { Investment by Jianyin } \\
\text { (Acquisition) }\end{array}$ & $\begin{array}{c}\text { United } \\
\text { Securities }\end{array}$ & $\begin{array}{l}\text { Huatai Securities } \\
\text { (Acquisition) }\end{array}$ \\
\hline $\begin{array}{l}\text { Southwest } \\
\text { Securities }\end{array}$ & $\begin{array}{l}\text { Investment by Jianyin } \\
\text { (Acquisition) }\end{array}$ & $\begin{array}{c}\text { Asia } \\
\text { Securities }\end{array}$ & $\begin{array}{l}\text { Huatai Securities } \\
\text { (Acquisition) }\end{array}$ \\
\hline $\begin{array}{l}\text { Zhongjin } \\
\text { Company }\end{array}$ & $\begin{array}{l}\text { Investment by Jianyin } \\
\text { (Holding) }\end{array}$ & $\begin{array}{c}\text { Xing'an } \\
\text { Securities }\end{array}$ & $\begin{array}{l}\text { Haitong Securities } \\
\text { (Trusteeship) }\end{array}$ \\
\hline $\begin{array}{c}\text { Tiantong } \\
\text { Securities }\end{array}$ & $\begin{array}{l}\text { Qilu Securities } \\
\text { (Trusteeship) }\end{array}$ & $\begin{array}{c}\text { Gansu } \\
\text { Securities }\end{array}$ & $\begin{array}{l}\text { Haitong Securities } \\
\text { (Trusteeship) }\end{array}$ \\
\hline $\begin{array}{c}\text { Xinjiang } \\
\text { Securities }\end{array}$ & $\begin{array}{l}\text { HongYuan Securities } \\
\text { (Trusteeship) }\end{array}$ & $\begin{array}{c}\text { Dapeng } \\
\text { Securities }\end{array}$ & $\begin{array}{c}\text { Changjiang Securities } \\
\text { (Acquisition) }\end{array}$ \\
\hline $\begin{array}{c}\text { Yinhe } \\
\text { Securities }\end{array}$ & $\begin{array}{l}\text { Central Huijin } \\
\text { (Holding) }\end{array}$ & $\begin{array}{c}\text { Jianqiao } \\
\text { Securities }\end{array}$ & $\begin{array}{l}\text { Western Securities } \\
\text { (Trusteeship) }\end{array}$ \\
\hline $\begin{array}{c}\text { Shenyin } \\
\text { Wanguo }\end{array}$ & $\begin{array}{l}\text { Central Huijin } \\
\text { (Holding) }\end{array}$ & $\begin{array}{c}\text { Xibei } \\
\text { Securities }\end{array}$ & $\begin{array}{l}\text { Nanjing Securities } \\
\text { (Trusteeship) }\end{array}$ \\
\hline Guotai Jun'an & $\begin{array}{l}\text { Central Huijin (joint } \\
\text { stock) }\end{array}$ & $\begin{array}{c}\text { Tianqin } \\
\text { Securities } \\
\end{array}$ & $\begin{array}{l}\text { Guo Yuan Securities } \\
\text { (Trusteeship) }\end{array}$ \\
\hline $\begin{array}{l}\text { Guangdong } \\
\text { Securities }\end{array}$ & $\begin{array}{l}\text { Securities investor } \\
\text { protection fund } \\
\text { (Trusteeship) }\end{array}$ & $\begin{array}{c}\text { Min'an } \\
\text { Securities }\end{array}$ & $\begin{array}{l}\text { Guosen Securities } \\
\text { (Acquisition) }\end{array}$ \\
\hline $\begin{array}{l}\text { China } \\
\text { Technology } \\
\text { Securities }\end{array}$ & $\begin{array}{l}\text { Securities investor } \\
\text { protection fund } \\
\text { (Trusteeship) }\end{array}$ & $\begin{array}{l}\text { Zhongfu } \\
\text { Securities }\end{array}$ & $\begin{array}{l}\text { Shanghai Securities } \\
\text { (Acquisition) }\end{array}$ \\
\hline $\begin{array}{l}\text { Zhongguancun } \\
\text { Securities }\end{array}$ & $\begin{array}{l}\text { Securities investor } \\
\text { protection fund } \\
\text { (Trusteeship) }\end{array}$ & $\begin{array}{l}\text { Wuzhou } \\
\text { Securities }\end{array}$ & $\begin{array}{l}\text { Donghai Securities } \\
\text { (Acquisition) }\end{array}$ \\
\hline $\begin{array}{l}\text { Huaxia } \\
\text { Securities }\end{array}$ & $\begin{array}{l}\text { Citic Securities } \\
\text { Investment by Jianyin } \\
\text { Joint Investment }\end{array}$ & $\begin{array}{l}\text { Northern } \\
\text { Securities }\end{array}$ & $\begin{array}{l}\text { Orient Securities } \\
\text { (Trusteeship) }\end{array}$ \\
\hline $\begin{array}{c}\text { Jintong } \\
\text { Securities }\end{array}$ & $\begin{array}{l}\text { Citic Securities } \\
\text { (Acquisition) }\end{array}$ & $\begin{array}{c}\text { Jiamusi } \\
\text { Securities }\end{array}$ & $\begin{array}{l}\text { Caida Securities } \\
\text { (Acquisition) }\end{array}$ \\
\hline $\begin{array}{l}\text { Wantong } \\
\text { Securities }\end{array}$ & $\begin{array}{l}\text { Citic Securities } \\
\text { (Acquisition) }\end{array}$ & $\begin{array}{l}\text { Hantang } \\
\text { Securities }\end{array}$ & $\begin{array}{c}\text { Cinda Asset } \\
\text { Management } \\
\text { Corporation } \\
\text { (Trusteeship) }\end{array}$ \\
\hline $\begin{array}{l}\text { Jinzhou } \\
\text { Securities }\end{array}$ & $\begin{array}{l}\text { GF Securities } \\
\text { (Acquisition) }\end{array}$ & $\begin{array}{l}\text { Liaoning } \\
\text { Securities }\end{array}$ & $\begin{array}{c}\text { Cinda Asset } \\
\text { Management } \\
\text { Corporation } \\
\text { (Trusteeship) }\end{array}$ \\
\hline
\end{tabular}

The securities industry environment in China undergoes profound changes, and full competition pattern has been formed with the deepening of marketing process in the securities market. Mergers and reorganization have become the most important choices of growth path faced for further developing securities industry from the perspective of macro economic background and attitude of regulation mechanism.

\section{MAIN FACTORS AFFECTING PROFIT MODEL OF} SECURITIES TRADER MERGER AND ACQUISITION BUSINESS IN CHINA

\section{A. Main problems in securities trader merger and acquisition process Structure similarity and service homogeneity}

Firstly, the varieties are similar after merger and acquisition by many securities traders from the perspectives of structure and service. Their structures are also similar. The business department generally regards occupation of market share as main objective of development. Investment is excessively injected after merger and acquisition. Operation and management scales are singly expanded, thereby securities companies after merger and acquisition can not be separated from the cycle of vicious competition finally. In addition, the merger and acquisition companies do not have sufficient innovation 
strength, and they are lack of characteristics, and pay attention to services in the aspect of hardware rather than attention to services in the aspect of software. Therefore, competition status of the acquirer can not be effectively improved after merger and acquisition, thereby leading to lower degree of differentiation. It is difficult to effectively use resources to meet the needs of different clients.

Currently, many securities traders claim to provide high quality and high value-added consulting services, and some securities even claim to provide comprehensive financial services. Therefore, broker strategies are improved to a brand-new level. However, how to provide the society with high-quality consulting services, or how to reform consulting service mode of business department or how to effectively combine broker system and research consulting platform after merger and acquisition, merger and acquisition enterprises do not adopt substantive measures aiming at the above-mentioned aspects. Therefore, the large securities traders after merger and acquisition do not have essential differences from the medium and small securities traders before merger and acquisition to some extent.

\section{B. Higher operating expenses}

Coarse management pattern has profound influence on many fields in China for long term. It is the same for the securities industry. China securities fields are protected by higher monopoly commission policy for long term from a macro point of view, therefore it has business characteristics of 'high cost' and 'high yield'. Cost and expense are main factors influencing profits of business department and securities traders. Currently, cost and expense of business department in securities traders mainly include the following eight aspects: (1) rent; (2) decoration amortization; (3) equipment amortization; (4) communication fee; (5) information cost; (6) occupation cost amortization; (7) personnel cost; (8) other change costs. Traditional securities business departments have more obvious expansion modes. The expansion mode is more prominent after merger and acquisition of securities traders. Many securities traders constantly decorate luxurious large rooms, medium rooms and retail halls after merger and acquisition. They have own protective trade seats, corresponding satellite market information and trading systems. Expansion in the above aspects leads to larger fixed costs of the business department. Financial statement data of the securities companies show that longterm prepaid expenses show significant increase trend. One securities company in Beijing is adopted as an example. After another securities company is merged, the area thereof is expanded to 2000 square meters or so, and one-year operating cost of the business department is about 6 to 7 million Yuan, including rent of 3 million Yuan, equipment depreciation of 500 to 800 thousand Yuan, long-term deferred charges of 600-800 thousand Yuan, communication, consultation, personnel cost and other costs of 2 million Yuan or so.

\section{Backward management and weak risk control ability}

Company management after M\&A has important influence on both acquiring company and the acquired company. However, some securities companies are lack of marketing ability after M\&A. They are lack of higher market awareness and product marketing awareness. They even have serious misconducts in management under some conditions. Some cases are shown in Tab.3. In fact, the above problems are also available aiming at most securities companies. However, if the management level does not pay enough attention and adopt measures for solution within effective time, the problems can break out in a concentrated mode once the market situation is falling.

TABLE III. ILLEGAL OPERATION CASES OF SECURITIES TRADERS

\begin{tabular}{|c|c|}
\hline $\begin{array}{c}\text { Illegal operation } \\
\text { events of securities } \\
\text { traders }\end{array}$ & Event causes \\
\hline $\begin{array}{l}\text { Liaoning Securities } \\
\text { is trusted by illegal } \\
\text { operation; }\end{array}$ & $\begin{array}{l}\text { It was related to manipulating stock prices of Linhai Securities. } \\
\text { Main capital chain of the shares was clearly broken. }\end{array}$ \\
\hline $\begin{array}{l}\text { Minfa Securities is } \\
\text { trusted by illegal } \\
\text { operation; }\end{array}$ & $\begin{array}{l}\text { Minfa Securities was checked, and it was found that capital of } 2 \\
\text { billion Yuan was missing illegally without proper reason. } \\
\text { Commissioned financial fund of at least } 900 \text { million Yuan is } \\
\text { obtained without proper reason in the company. }\end{array}$ \\
\hline $\begin{array}{l}\text { Deheng, Hengxin, } \\
\text { Zhongfu and } \\
\text { Hantang Securities } \\
\text { Companies are } \\
\text { trusted by illegal } \\
\text { operation; }\end{array}$ & $\begin{array}{l}\text { Commissioned financial management of Deheng Securities } \\
\text { Company can not be cashed at maturity mainly because of loss } \\
\text { of fund investment stock market. Hantang has illegal operation } \\
\text { in treasury bond repurchase and self-operated business. The } \\
\text { estimated loss quantity is up to one hundred million Yuan. } \\
\text { Dexin and Zhongfu are related to Delong. 'Three Previous } \\
\text { Stocks' of Delong suffer from average drop of } 70 \% \text { or so. }\end{array}$ \\
\hline $\begin{array}{l}\text { Southern Securities } \\
\text { is taken over } \\
\text { administratively. }\end{array}$ & Treasury bond repurchase fund is broken. \\
\hline $\begin{array}{l}\text { Xinhua Securities is } \\
\text { withdrawn. }\end{array}$ & $\begin{array}{l}\text { Xinhua Securities cooperated with Zhuyaomin for supporting } \\
\text { Wikipedia Pharmaceutical, it was deeply trapped. Registered } \\
\text { fund of } 200 \text { million Yuan was completely lost. }\end{array}$ \\
\hline
\end{tabular}

V. ENVIRONMENT FACTORS AFFECTING PROFIT MODEL OF MERGER AND ACQUISITION BUSINESS OF SECURITIES TRADERS

\section{A. Influence of securities market situation on securities trader mergers and acquisitions}

Although economy is developed well in China in recent years, self-operation and assets management suffer from serious loss in many traditional businesses. Economic business profitability is declined due to transaction volume contraction and decline in the commission. Compared with small and medium-sized securities companies, large companies have stronger ability to resist pressure. However, small and medium-sized securities companies seem to be fragile in the stock market with constant changes.

\section{B. Influence of system factors on mergers and acquisitions of securities traders}

Firstly, China Securities Regulatory Commission announces that floating commission system is implemented in China securities market. In addition, the upper limit can not be higher than $0.3 \%$. Economic business occupies a certain proportion in the income composition of securities trader merger and acquisition business in China. Therefore, it is obvious that commission adjustment has important influence on mergers and acquisitions of securities traders in China, and business performance of securities traders.

Secondly, stock issuing system in China is changed from previous channel system into sponsor system. One qualified sponsoring institution can sponsor a certain number of enterprises at the same time under the sponsor 
system with corresponding cumulative effect. The sponsoring enterprise quantity has certain dynamic feature aiming at one securities trader, which has inevitable and important linkage with own real strength and performance. In addition, sponsoring institution and sponsor representatives have two-way choice interaction relationship. Therefore, free competition pattern of issuance underwriting business among securities traders can be constantly aggravated, thereby affecting M\&A income.

\section{CONSTRUCTION OF PROFIT MODEL OF SECURITIES TRADER M\&A BUSINESS IN CHINA}

\section{A. Active expansion of financing channels}

Securities trader merger and acquisition should be supported by a lot of fund. Both cash purchase and noncash purchase are dependent on foundational function of cash to certain extent. Less financing amount and narrow financing channel are urgent problems in the M\&A process of securities traders in China. Financing channels should be actively expanded in order to solve the problem, thereby promoting integration of securities traders. Existing conditions show that China securities trader can enter inter-bank bond market, and participate in treasury bond repurchase business. They also can be listed publicly for raising fund. Company bonds can be issued for raining fund, and these are active guarantees to carry out business and M\&A in China.

\section{B. Construction of international strategy pattern}

The internationalization trend has become an important trend in the development of securities market in China along with constant deepening of world economic integration trend. International strategy mode of securities traders has the essence that demand of economic globalization development can be maximally adapted to a certain extent. Domestic and foreign investors are linked with the raisers. Fund optimization allocation can be implemented all over the world. Therefore, internationalization problem of securities traders can be treated by strategic approach, and it is recognized that effective expansion of international survival space can weaken pressure due to excessive competition in domestic market objectively without doubts. Secondly, own international development route can be strategically selected, and the focus can be transferred to overseas market in good time. Information of international investors and domestic raisers can be comprehended. The gap with overseas securities traders can be shortened from many perspectives. In addition, the securities industry development in China was started late compared with western developed countries. It is a young industry, experience of foreign securities companies can be learned and adopted as reference from many aspects. Therefore, more international experience can be adopted as reference aiming at merger and acquisition mode.

\section{Correct control of balance between administrative power and market power in merger, acquisition and reorganization process}

When foreign securities traders implement merger, acquisition and reorganization, the process mainly relies on market power. Merger, acquisition and reorganization has own characteristics aiming at securities traders in China. Actual situation in China shows that merger, acquisition and reorganization of securities traders should not merely depend on market power because deep-rooted market operation mode in China has defects on one hand, and current economic development is not perfect. Therefore, merger, acquisition and reorganization of securities traders also depend on government participation and promotion role sometimes. Therefore, relationship between them should be handled well in concrete implementation process. It is necessary to determine plan through careful analysis and multi-party discussion. If the integrated structure is positive, merger and acquisition can be effectively driven by local government perfection, thereby ensuring that small and medium-sized securities traders can integrate under the condition of stable operation and better assets quality maximally. Costs of various securities traders in China for merger, acquisition and reorganization can be lowered for long term. Securities trader can not be acquired during bankruptcy, and similar problems can not be produced.

\section{Innovation model of investment banking business}

Position of investment banking business is critical in the securities trader business, which can help the investment banks to effectively expand space and business. Many investment banking businesses are concentrated in securities issuance underwriting traditional project aiming at investment banking businesses of China domestic securities traders. However, other businesses are still in the initial stage, such as asset securitization, securities collateral financing, advisory services, etc. Enterprise merger and acquisition business do not have corresponding attention as an independent business. Situation in the United States shows that large securities traders generally set up special merger and acquisition departments correspondingly. The department is responsible for specially engaging in merger and acquisition business. Main routes and hotspot issues of economic reform marketization must be firmly controlled in investment banking business in order to crate new profit model aiming at securities traders in China. Therefore, innovation business category adapting to international competition in the future can be implemented maximally. Therefore, securities trader M\&A behavior essentially belongs to a process of resource integration and configuration. In the M\&A process, investment banks have main task of regarding target company as commodity. Actual value, market value and potential value of the commodity should be compared, and they are utilized through reconfiguration of resources, and potential value thereof can be explored.

\section{CONCLUSIONS}

In general, economy is developed at high speed currently, and securities traders should profoundly realize own industry risks. The government also should recognize that the root of the existing securities system and institution, which should be rectified fundamentally. Securities traders can not be trapped into the reorganization due to superficial and shallow merger and reorganization, and such risk can not be reproduced in the future. Therefore, successful cases in western developed 
countries should be adopted as reference, which should be combined with realistic condition in China, thereby driving merger and reorganization among securities traders. Meanwhile, China securities traders should absorb development experience of China commercial banks and insurance companies during the development process. This is also one important trend of China securities traders in future development.

\section{REFERENCES}

[1] Li Mingliang, Ni Yujuan, Zhou Hongrong. "Thinking on implementing mergers and acquisition fund operation model by securities traders," Innovation and Development: China Securities Industry 2012 Collected Papers. 2012.

[2] Zhang Hailong. "Analysis on profit model characteristics of China securities traders and risk prevention," Journal of Tianshui Normal University, 2014, vol. 23, pp. 26-28.

[3] Ke Jingmin. "Reason for flourishing securities trader merges and acquisitions," China Securities and Futures, 2013, vol. 11, pp. 2022.
[4] Liu Jianqing. "Research on M\&A financial risk in China securities company," Guangdong University of Finance and Economics, 2014, vol. 12, pp. 33-35.

[5] Khmelenko G G, Khmelenko O V. "Development of measures on increase of economic security of merger and acquisition transactions in ukraine," Problems of Economy, 2013, vol. 3 , pp. 161-171.

[6] Pan D Y. "Implications on National Security Censorship of EU Foreign Merger and Acquisition for China," Journal of Hubei University of Economics, 2013, vol. 8, pp. 89-91.

[7] Stultz J C, Bradley J A. “Missions preempt merger," Officer, 2013, vol. 2, pp. 110-113.

[8] Kokkoris I, Shelanski H. "EU Merger Control," Oxford University Press, 2014.

[9] Delorenzo M. "FEMA and the Merger with DHS: Did it Impact FEMA's Autonomy and Performance," University of illinois at chicago, 2013.

[10] Gerrie S. "First Security, Wells merger not a done deal," Las Vegas Business Press, 2012, vol. 5, pp. 53-57. 